\title{
The role of cover crops in irrigated systems: Soil salinity and salt leaching
}

\author{
J.L. Gabriel, P. Almendros, C. Hontoria, M. Quemada
}

\begin{abstract}
A B S T R A C T
Soil salinity and salt leaching are a risk for sustainable agricultural production in many irrigated areas. This study was conducted over 3.5 years to determine how replacing the usual winter fallow with a cover crop (CC) affects soil salt accumulation and salt leaching in irrigated systems. Treatments studied during the period between summer crops were: barley (Hordeum vulgare L.), vetch (Vicia villosa L.) and fallow. Soil water content was monitored daily to a depth of $1.3 \mathrm{~m}$ and used with the numerical model WAVE to calculate drainage. Electrical conductivity (EC) was measured in soil solutions periodically, and in the soil saturated paste extracts before sowing CC and maize. Salt leaching was calculated multiplying drainage by total dissolved salts in the soil solution, and use to obtain a salt balance. Total salt leaching over the four winter fallow periods was $26 \mathrm{Mgha}^{-1}$, whereas less than $18 \mathrm{Mg} \mathrm{ha}^{-1}$ in the presence of a CC. Periods of salt gain occurred more often in the CC than in the fallow. By the end of the experiment, net salt losses occurred in all treatments, owing to occasional periods of heavy rainfall. The CC were more prone than the fallow to reduce soil salt accumulation during the early growth stages of the subsequent cash crop.
\end{abstract}

\section{Introduction}

Salt accumulation in the soil profile because of poor irrigation water or certain agricultural practices is a risk to sustainable agricultural production in many irrigated areas of the world (Paranychianakis and Chartzoulakis, 2005; Feng et al., 2005). Salinity has already affected more than 80 million ha of arable land in many areas of the world, and it continues to increase (FAOSTAT, http://www.fao.org/nr/water/aquastat/main/index.stm). In the Mediterranean region, salinity is a principal cause of yield reduction and even land degradation (Lambers, 2003). Leaching, the net downward movement of soil water and salt through the root zone, is the key to salinity control (Oster, 1994). Under semiarid conditions, the amount and distribution of rainfall are rather variable, and the leaching of salts during the non-growing season can also vary. Therefore, the effects of new irrigation practices and cropping strategies on salt accumulation should always be tested prior to introduction to determine their suitability for irrigated agricultural areas.

Applying an excess of irrigation water to avoid salt accumulation in the soil profile is a common practice (Ayers and Wescott, 1985). Most water and salt losses occurs during the crop growing season and are dependent on the leaching fraction (Vázquez et al., 2006). However, over-watering might not be sustainable in the long term, owing to the enforcement of EU directives on ground water quality and the low water- and nitrogen-use efficiency of this practice (Díez et al., 2000). Reducing the leaching fraction to minimise water loss during the irrigation period has been proposed as an alternative irrigation schedule, but care should be taken because can lead salt to accumulate in the soil after the harvest (Román et al., 1999). Evaluation of this new irrigation schedule in central Spain (Caballero et al., 2001) showed that, to avoid soil salinity constraints, occasional drainage should occur during the non-growing season to induce salt leaching. Therefore, cropping strategies that affect the water balance during that winter intercropping period should be tested for their effect on the leaching pattern.

The adoption of cover crops (CC) has often been limited in dry regions mainly because of water competition with the cash crop (Unger and Vigil, 1998). Nevertheless, in irrigated areas where CC establishment is feasible, consequent soil and/or nutrient conservation could increase the sustainability of cropping systems. Replacing bare fallow with CC may enhance the aggregate stability (Roberson et al., 1991) and water retention capacity (Quemada and Cabrera, 2002) of the soil, which are two important characteristics in irrigated land. Nevertheless, $\mathrm{CC}$ increase evapotranspiration and reduce water percolation beyond the root system during the nongrowing season; therefore, they could lead to salt accumulation in the upper soil layers. A long-term evaluation of potential salt accumulation in the soil profile is, therefore, necessary to ensure that the potential disadvantages originating from soil salt accumulation are compensated for by the advantages of cover cropping.

In addition, excess irrigation to prevent salt accumulation causes salts to leach out of the soil profile. Watershed studies have shown that return flows from irrigated agriculture are a major diffuse 
Table 1

Soil physical and chemical properties.

\begin{tabular}{|c|c|c|c|c|}
\hline Depth $(\mathrm{cm})$ & $0-23$ & $23-40$ & $40-70$ & $70-120$ \\
\hline $\mathrm{pH}(1: 2.5)$ & 8.16 & 8.06 & 8.02 & 7.84 \\
\hline Organic $C\left(\mathrm{~g} \mathrm{~kg}^{-1}\right)$ & 18.5 & 17.0 & 12.7 & 13.0 \\
\hline $\mathrm{CEC}^{\mathrm{a}}$ (meq. $\left.100 \mathrm{~g}^{-1}\right)$ & 8.7 & 11.7 & 11.9 & 8.1 \\
\hline $\mathrm{CO}_{3}\left(\mathrm{gCO}_{3}^{2-} \mathrm{kg}^{-1}\right)^{\prime}$ & 198.0 & 201.3 & 159.0 & 181.0 \\
\hline Gypsum $\left(\mathrm{g} \mathrm{kg}^{-1}\right)$ & 8.8 & 10.7 & 11.0 & 12.2 \\
\hline \multicolumn{5}{|l|}{ Texture } \\
\hline Sand ( $\left.\mathrm{g} \mathrm{kg}^{-1}\right)$ & 260 & 250 & 250 & 250 \\
\hline Silt $\left(\mathrm{g} \mathrm{kg}^{-1}\right)$ & 490 & 510 & 520 & 460 \\
\hline Clay $\left(\mathrm{g} \mathrm{kg}^{-1}\right)$ & 250 & 240 & 230 & 290 \\
\hline
\end{tabular}

a Cation exchange capacity.

contributor of salt contamination in water bodies (Aragüés and Tanji, 2003; Causapé et al., 2004). Saline waters have a negative impact not only on aquatic fauna and vegetation, but also on crop yields and industrial processes (Wichelns and Oster, 2006). The degree of this irrigation-induced pollution is complex and depends on hydro-geological characteristics, water supply quality, agriculture techniques and the drainage system (Aragüés and Tanji, 2003). Agricultural practices that lead to a reduction in salt leaching may help to mitigate the diffuse pollution problem caused by return flows from irrigated areas.

A reasonable hypothesis is that $\mathrm{CC}$ grown after irrigated crops in dry regions could reduce salt leaching and lead to salt build up in the soil. The effect of CC on soil salinity is particularly relevant when water application is adjusted to fit crop needs. This study was conducted over 3.5 years to determine how replacing the usual winter fallow with a CC affects soil salt accumulation and salt leaching in irrigated systems.

\section{Material and methods}

\subsection{Experimental setup}

The study was conducted over 3.5 years at La Chimenea Field Station $\left(40^{\circ} 03^{\prime} \mathrm{N}, 03^{\circ} 31^{\prime} \mathrm{W}, 550 \mathrm{~m}\right.$ a.s.l.), located in the central Taxus river basin near Aranjuez (Madrid, Spain). The soil at the field site is a silty clay loam (Typic Calcixerept; Soil Survey Staff, 2003) with a basic pH, high permeability and low stone content throughout the soil profile. Gypsum content increased with depth reaching $1.2 \%$ in the deepest layer, and carbonate content was moderately high. The most relevant soil characteristics are presented in Table 1. Cation exchange capacity was determined after saturation with $\mathrm{BaCl}_{2}$ (Sumner and Miller, 1996) and total organic carbon by the Walkley-Black method (Nelson and Sommers, 1996). Calcium carbonate was determined by the volumetric calcimeter method (Loeppert and Suarez, 1996) and gypsum by differential water loss (Artieda et al., 2006). The climate of the area is Mediterranean semiarid (Papadakis, 1966) with high interannual variability. The mean annual temperature is $14.2^{\circ} \mathrm{C}$, and the average annual rainfall is $345 \mathrm{~mm}$, being lower during summer and higher during autumn (Table 2). Measurements of temperature, humidity, radiation, PAR (photosynthetically active radiation) and wind were recorded throughout the experiment period by a CR23X micrologger from Campbell Scientific (Logan, UT, USA). The experiment was carried out in a field that was fallow for a minimum of two years before the beginning of the trial.

Twelve plots $(12 \mathrm{~m} \times 12 \mathrm{~m})$ were randomly distributed into four replicates of three cover cropping treatments: barley (Hordeum vulgare L.), vetch (Vicia villosa L.) and fallow. Cover crops were broadcast by hand over maize stubble and covered with a shallow cultivator in October. All treatments were treated with one application of Glyphosate 2\% (N-phosphonomethyl glycine) in March and sown with maize (Zea mays L.) three weeks later. The maize was 
Table 3

Reference evapotranspiration (ETo), crop evapotranspiration (ETc), irrigation, and precipitation during the maize cropping periods of the experiment.

\begin{tabular}{lccc}
\hline$(\mathrm{mm})$ & $2007^{\mathrm{a}}$ & 2008 & 2009 \\
\hline ETo & 745.3 & 721.2 & 844.4 \\
ETc & 643.7 & 624.9 & 716.1 \\
Irrigation & 575.7 & 533.7 & 656.4 \\
Rain & 106.6 & 142.0 & 45.4 \\
Total water input & 682.3 & 675.7 & 701.8 \\
Total water input/ETc & 1.06 & 1.08 & 0.98 \\
\hline
\end{tabular}

a Maize cropping period last from seeding (beginning of April) to harvest (end of September)

harvested in early autumn, and the residue was removed from the plots. Water from the Taxus river was uniformly applied to maize by a sprinkle irrigation system $\left(12 \mathrm{~m} \times 12 \mathrm{~m}, 9.5 \mathrm{~mm} \mathrm{~h}^{-1}\right)$ according to crop evapotranspiration (ETc) requirements calculated by the FAO method (Allen et al., 1998). Reference evapotranspiration (ETo) was calculated using the Penman-Monteith model, and the crop coefficient was obtained following the relationship for maize in semiarid conditions (Martínez-Cob, 2008). Irrigation was adjusted according to rainfall to support ETc, and the overall water input/ETc ratio approached unity during the maize cropping season (Table 3). All treatments received the same amount of water and a flow meter was installed just before the experiment to measure the amount of water applied. Cover crops were established on residual moisture and no irrigation was applied. A more detailed description of the experimental site and design can be found in Gabriel and Quemada (2011).

Soil water content was monitored daily using EnviroSCAN ${ }^{(B)}$ capacitance probes (Sentek Pty Ltd., Stepney, Australia), as described in detail by Paltineanu and Starr (1997). Sixty-three capacitance sensors were mounted on nine plastic extrusions (three repetitions per treatment), introduced into nine access pipes and connected to three data loggers. To ensure measurement reliability, a normalisation procedure was conducted using reference readings obtained by exposing each sensor to air and water $\left(\approx 20^{\circ} \mathrm{C}\right)$. The sensors were centred at $10,30,50,70,90$, 110 and $130 \mathrm{~cm}$ below the soil surface in each plastic extrusion, and normalised readings were registered every hour. A daily average was obtained from the hourly readings for the respective soil layers: $0-20$ (10), 20-40 (30), 40-80 (60), 80-120 (100) and $120-140(130) \mathrm{cm}$. The average readings were transformed into soil volumetric water content by means of a calibration equation, which was obtained for this equipment at this experimental site (Gabriel et al., 2010). The soil water content data set was later used in combination with a numerical model to obtain the water balance.

\subsection{WAVE model calibration, validation and application}

The mechanistic-deterministic WAVE model (Vanclooster et al., 1996) was used to describe the water flow in the vadose zone. Estimates of crop parameters required to simulate crop evapotranspiration (leaf area index, crop coefficient and active root depth) were based on direct measurements. An inverse calibration was performed, and the hydraulic parameters were optimised with a portion of the available measurements on volumetric soil moisture content. The remainder of the data set was validated with two maize periods $(2008,2009)$ and three fallow and cover crop periods (2007/2008, 2008/2009, and 2009/2010). Once the WAVE model was calibrated and validated for the soil and the crops, it was applied to the three replications for each treatment over the whole study period. Information about drainage was obtained from the model's output and was averaged for each treatment. A more detailed description of the model and the calibration and validation procedures can be found in Gabriel et al. (2012).

\subsection{Salt concentration of the irrigation water and soil solution}

In each of the 12 plots, three ceramic cups were installed at least $1.5 \mathrm{~m}$ from the nearest cup, EnviroSCAN ${ }^{\circledR}$ capacitance probe, soil sampling point or plot edge. The cups were placed at $1.2 \mathrm{~m}$ in depth, and the soil solution was sampled and transferred to a storage bottle by means of a hand-operated vacuum pump connected to a capillary tube every 15 days or after $20-\mathrm{mm}$ rain (Lord and Shepherd, 1993). These cups were carefully installed to avoid preferential flow and maintained under suction close to $333 \mathrm{~cm}$ throughout the experimental period. The soil solution samples were stored in a freezer until subsequent analysis.

Electrical conductivity was measured with a Crison 525 conductimeter (Crison, Barcelona) in all soil solution samples collected from the ceramic cups $(n=832)$ and in irrigation water samples collected periodically $(n=24)$. A subset $(n=62)$ of the soil solution and irrigation water samples distributed uniformly across the experiment was selected for more detailed solute concentration analysis. Determination of $\mathrm{Ca}^{2+}, \mathrm{Mg}^{2+}, \mathrm{K}^{+}$and $\mathrm{Na}^{+}$was done by optical emission spectrometry with an ICP-OES plasma spectrometer (Iris advantage ERS Duo 14034100, Thermo Fisher Scientific Inc., Waltham, MA, US). $\mathrm{SO}_{4}{ }^{2-}$ and $\mathrm{Cl}^{-}$were analysed by ion chromatography (Metrohm 761 Compact IC, Herisau, Switzerland) and $\mathrm{CO}_{3}{ }^{2-}$ and $\mathrm{HCO}_{3}-$ by alkalimetric titration. Nitrate concentrations in the soil solution were determined by spectrophotometry after reduction with a cadmium column (Keeney and Nelson, 1982). A Crinson 217 meter (Crison, Barcelona) was used to measure $\mathrm{pH}$. Solute concentration and EC data series were analysed using linear correlation.

Total dissolved salts (TDS) were estimated by adding the solute concentrations for each sample of the soil solution and irrigation water subset. A single linear relationship was obtained by regression analysis of solution EC on TDS. This relationship was used to calculate TDS based on EC measured in all of the soil solution and irrigation water samples collected during the experiment. Mean TDS was calculated from the soil solution samples for each sampling date and treatment.

\subsection{Salt leaching and net salt losses}

Salt leaching at $1.2 \mathrm{~m}$ for the ceramic cup sampling intervals was calculated as the product of the mean TDS of the soil solution times the drainage obtained with the WAVE model during the sampling interval. When soil solution was collected in less than $50 \%$ of the ceramic cups in a treatment, the drainage was considered zero. Salt leaching for the soil solution sampling intervals was summed to obtain cumulative salt leaching to below $1.2 \mathrm{~m}$ by period (crop or intercrop) and for the whole experimental time. It was assumed that water percolation below $1.2 \mathrm{~m}$ would leach salt into the ground water table (at a mean depth of $4.5 \mathrm{~m}$ ) because of the high permeability of the belowground layers (Roquero et al. 2001). The salt balance for the soil solution sampling intervals was calculated as the difference between the salt inputs from irrigation and precipitation and the salt leaching below $1.2 \mathrm{~m}$ in depth. Salt input from irrigation water was calculated as the product of the irrigation water volume and the TDS of the water for each period. Salt input from precipitation was obtained considering that the EC for rain equals $0.0035 \mathrm{~S} \mathrm{~m}^{-1}$ (Hontoria et al., 2003). The total crop uptake was assumed to be offset by salts applied in fertiliser, both of which are negligible compared to the quantities measured in the salt balance. The salt balance by period and for the whole experiment was obtained by adding together the salt balances for each soil solution sampling interval. 
Table 4

Salt concentrations, electrical conductivity (EC), and $\mathrm{pH}$ of soil solution and irrigation water.

\begin{tabular}{|c|c|c|c|c|c|c|c|c|c|c|}
\hline & $\mathrm{Ca}^{2+}$ & $\mathrm{Mg}^{2+}$ & $\mathrm{Na}^{+}$ & $\mathrm{K}^{+}(\mathrm{ppm})$ & $\mathrm{Cl}^{-}(\mathrm{ppm})$ & $\mathrm{SO}_{4}^{2-}$ & $\mathrm{COH}_{3}^{-}$ & $\mathrm{NO}_{3}^{-}$ & $\mathrm{pH}$ & $\mathrm{EC}\left(\mathrm{S} \mathrm{m}^{-1}\right)$ \\
\hline Soil solution $n=57$ & $634 \pm 146^{\mathrm{a}}$ & $197 \pm 96$ & $355 \pm 118$ & $1.43 \pm 0.8$ & $811 \pm 394$ & $1636 \pm 337$ & $84 \pm 26$ & $56 \pm 62$ & $7.9 \pm 0.1$ & $0.53 \pm 0.12$ \\
\hline Irrigation water $n=5$ & $118 \pm 16$ & $33 \pm 14$ & $86 \pm 42$ & $1.96 \pm 1.1$ & $102 \pm 53$ & $407 \pm 67$ & $38 \pm 3$ & $0.3 \pm 0.3$ & $7.5 \pm 0.1$ & $0.12 \pm 0.03$ \\
\hline
\end{tabular}

a Standard error (SE).

Table 5

Correlation matrix between ionic concentrations and electrical conductivity (EC).

\begin{tabular}{|c|c|c|c|c|c|c|c|c|}
\hline & $\mathrm{Mg}^{2+}$ & $\mathrm{Na}^{+}$ & $\mathrm{K}^{+}$ & $\mathrm{Cl}^{-}$ & $\mathrm{SO}_{4}^{2-}$ & $\mathrm{COH}_{3}^{-}$ & $\mathrm{NO}_{3}{ }^{-}$ & $\mathrm{EC}$ \\
\hline $\mathrm{Ca}^{2+}$ & $0.505^{* * *}$ & $0.486^{* * 4}$ & 0.134 & $0.808^{* * *}$ & $0.422^{* * *}$ & $0.265^{\circ}$ & 0.210 & $0.732^{* * *}$ \\
\hline $\mathrm{Mg}^{2+}$ & & $0.540^{* * 1}$ & $0.371^{* *}$ & $0.639^{* * *}$ & $0.485^{* * *}$ & 0.147 & 0.233 & $0.375^{* *}$ \\
\hline $\mathrm{Na}^{+}$ & & & 0.110 & $0.488^{* * *}$ & $0.669^{* * *}$ & $0.464^{* * *}$ & 0.133 & $0.561^{* * *}$ \\
\hline $\mathrm{K}^{+}$ & & & & 0.243 & -0.052 & $-0.289^{\circ}$ & 0.039 & $0.312^{*}$ \\
\hline $\mathrm{Cl}^{-}$ & & & & & 0.142 & 0.124 & 0.195 & $0.433^{* * *}$ \\
\hline $\mathrm{SO}_{4}^{2-}$ & & & & & & $0.473^{* * *}$ & 0.048 & $0.832^{* * *}$ \\
\hline $\mathrm{COH}_{3}{ }^{-}$ & & & & & & & 0.001 & 0.271 \\
\hline $\mathrm{NO}_{3}{ }^{-}$ & & & & & & & & 0.178 \\
\hline
\end{tabular}

Significant at probably levels of $0.001(n=62)$

** Significant at probably levels of $0.01(n=62)$.

* Significant at probably levels of $0.05(n=62)$.

\subsection{Soil salt accumulation}

Before sowing the $\mathrm{CC}$ and maize, four $1.2 \mathrm{~m}$-deep holes were excavated with an Eijkelkamp ${ }^{\circledR}$ (Giesbeek, The Netherlands) helicoidal auger in each plot to monitor soil salt accumulation. Samples were taken from 6 depths mixing the soil obtained from the four holes every $0.20 \mathrm{~m}$. The electrical conductivity of the saturated paste extract (ECe) was measured with a Crison 525 conductimeter (Crison, Barcelona) in each soil layer and treatment (Rhoades, 1996). Total dissolved salts $\left(\mathrm{g} \mathrm{L}^{-1}\right)$ of the soil were estimated from the previously obtained linear regression equation between EC and TDS. The amount of salt per area $\left(\mathrm{Mg} \mathrm{ha}^{-1}\right)$ of each horizon was calculated as the respective TDS multiplied by the bulk density of the soil and the layer thickness.

\section{Results}

\subsection{Irrigation water and soil solution salt concentrations}

Salt concentrations in the soil solution were higher and more variable than in the irrigation water (Table 4). The mean EC of the soil solution at $1.2 \mathrm{~m}$ deep was $0.53 \mathrm{~S} \mathrm{~m}^{-1}$ with a coefficient of variation (CV) of $32 \%$. The mean $\mathrm{EC}$ of the irrigation water was $0.12 \mathrm{~S} \mathrm{~m}^{-1}$ with a CV of $17 \%$, indicating low salt content and small variations for the irrigation water throughout the experiment. The main anions were $\mathrm{SO}_{4}{ }^{2-}, \mathrm{Cl}^{-}$, and to a lesser extent $\mathrm{HCO}_{3}{ }^{-}$. The main cations were $\mathrm{Ca}^{2+}, \mathrm{Na}^{+}$, and to a lesser extent $\mathrm{Mg}^{2+}$. All ions were at higher concentrations in the soil solution than in the irrigation water except for $\mathrm{K}^{+}$, which makes a small contribution to the TDS. Electrical conductivity was highly correlated with the most dominants ions and not with $\mathrm{HCO}_{3}{ }^{-}$or $\mathrm{NO}_{3}{ }^{-}$(Table 5). No differences or trends were observed between the different treatments with respect to the ion concentrations in the soil solution from any sampling date, except for $\mathrm{NO}_{3}{ }^{-}$, which deserved a specific analysis (Gabriel et al., 2012).

The mean TDS of the irrigation water was $848 \mathrm{mg} \mathrm{L}^{-1}$ and the CV was $17 \%$. The mean TDS of the soil solution was $3817 \mathrm{mg} \mathrm{L}^{-1}$ and the CV was $32 \%$. When forced to pass through the origin, the regression line between TDS and the EC of the soil solution explains $85 \%$ of the TDS variation in the data set $(n=62)$ (Fig. 1). The regression coefficient found for the linear regression (7.19) falls within the range (5.5-9.0) specified by the APHA (American Public Health Association, 1995). The regression equation obtained from these data was used to estimate TDS $\left(\mathrm{g} \mathrm{L}^{-1}\right)$ from laboratory EC measurements in samples of irrigation water, soil solutions and saturated paste extracts to calculate the net salt balance.

The seasonal trend of the EC values in the soil solution at $1.2 \mathrm{~m}$ did not vary between treatments (Fig. 2). The mean EC of the soil solution was $0.53 \mathrm{~S} \mathrm{~m}^{-1}(\mathrm{CV}=28 \%)$ for the fallow treatment, 0.56 $(\mathrm{CV}=55 \%)$ for the vetch, and $0.52(\mathrm{CV}=37 \%)$ for the barley. The duration of the drainage periods over the 3.5 years of the study based on soil solution sampling was greater for the fallow (602 d) than for the vetch ( $497 \mathrm{~d}$ ) or barley (401 d) treatments. Seasonal EC fluctuations were not related to changes in drainage below $1.2 \mathrm{~m}$; therefore, salt leaching calculations should be based on both salt concentration and drainage volume.

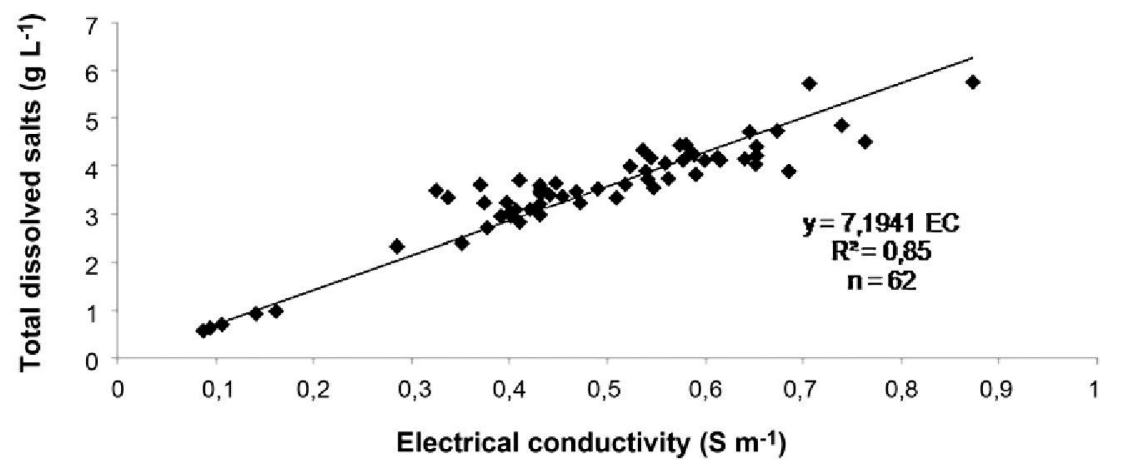

Fig. 1. Regression of total dissolved salts (TDS) on electrical conductivity (EC) for the soil solution and irrigat ion water. 


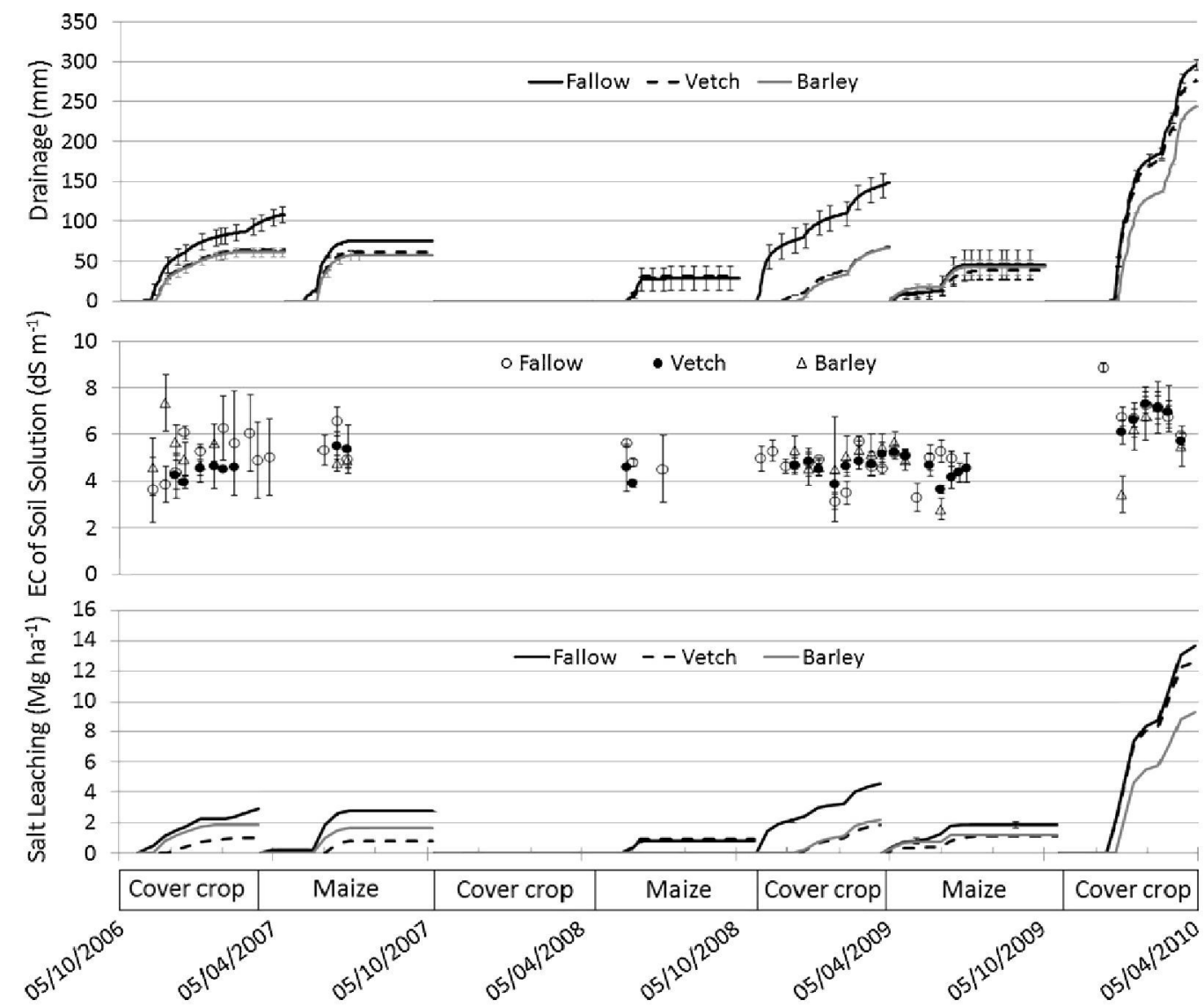

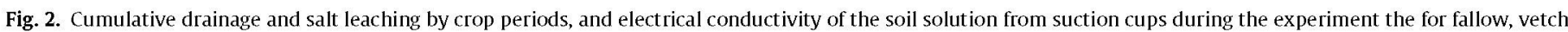
and barley treatments. Error bars represent the standard error.

\subsection{Salt leaching and salt balance}

Net salt gains and losses were calculated for each maize and intercrop period. Salt leaching was obtained by combining drainage, as estimated by WAVE, together with concentrations measured in the suction cups at the corresponding sampling times (Fig. 2). The total amount of salt leached during the study period was greater in the fallow treatment $\left(26.2 \mathrm{Mg} \mathrm{ha}^{-1}\right)$ than in either cover crop, being similar for vetch $\left(18.5 \mathrm{Mg} \mathrm{ha}^{-1}\right)$ and barley (16.4 $\left.\mathrm{Mg} \mathrm{ha}^{-1}\right)$. Differences in salt leaching during the maize period only appeared during spring in accordance with drainage reduction, and they were significant in 2007 and 2008 when the leaching of salts in the $\mathrm{CC}$ was lower than in the fallow treatment. Most of the salt leaching took place during the intercrop period, representing about $80 \%$ of the total salts leached during the study in all treatments. These intercrop periods were characterised by highly variable salt discharge, ranging from null in 2007/2008 to more than $9.0 \mathrm{Mg} \mathrm{ha}^{-1}$ in 2009/2010. During this last period, barley reduced salt leaching by $4.0 \mathrm{Mg} \mathrm{ha}^{-1}$ with respect to the fallow treatment. When drainage occurred, whether during a maize or intercrop period, salt leaching in the fallow treatment was always equal to or greater than that in the cover crop treatments.

The salt concentrations of the irrigation and precipitation water varied little throughout the experiment, and thus a mean value was used to estimate salt input. Electrical conductivity was lower for the precipitation than for the irrigation water; therefore, salt input was linked to the maize periods and was equal for all treatments $\left(14.9 \mathrm{Mg} \mathrm{ha}^{-1}\right)$. Fertiliser application was the same for all treatments and was assumed to be offset by plant uptake. No difference was observed in maize biomass production between the treatments (Gabriel and Quemada, 2011); therefore, nutrient uptake was assumed to be similar between the treatments.

Net salt loss, obtained as the difference between salt inputs and salt leaching, varied depending on the year and season (Fig. 3). In the fallow treatment, net salt losses from the soil profile were observed during the entire experimental period except for two short intervals (four weeks in 2008 and nine in 2009) at the end of the maize cycle that occurred after a prolonged period of low drainage. With the $\mathrm{CC}$, periods of net salt gain were more prolonged (from January 2008 to November 2009), but, at the end of the experiment, net salt losses occurred in both the vetch and barley treatments. Over the entire study period, net salt losses were greater in the fallow treatment $\left(-12.0 \mathrm{Mg} \mathrm{ha}^{-1}\right)$ than in either cover crop, being similar for vetch $\left(-3.7 \mathrm{Mg} \mathrm{ha}^{-1}\right)$ and barley $\left(-1.6 \mathrm{Mg} \mathrm{ha}^{-1}\right)$.

\subsection{Salt accumulation in the soil profile}

At the beginning of the experiment, the ECe was uniform throughout the soil profile with a value of approximately $0.3 \mathrm{~S} \mathrm{~m}^{-1}$ (Fig. 4). Values of ECe varied from 0.07 to $0.45 \mathrm{~S} \mathrm{~m}^{-1}$ for the different soil layers during the experimental time, indicating that salt accumulation in the soil profile was a dynamic process. In the deepest layers, only slight differences were observed between sampling dates, and differences in TDS between treatments were never significant. In the upper layers, ECe varied throughout the experimental period, and relevant differences between treatments appeared at two sampling dates, April 2008 and 2010, just before the planting of maize (Table 6). Total dissolved salts in the soil profile were higher in the fallow than in the cover crop treatments, and this finding was due to differences in the upper soil layers. Particularly during the 2009/10 intercrop period, a large decline in TDS was 


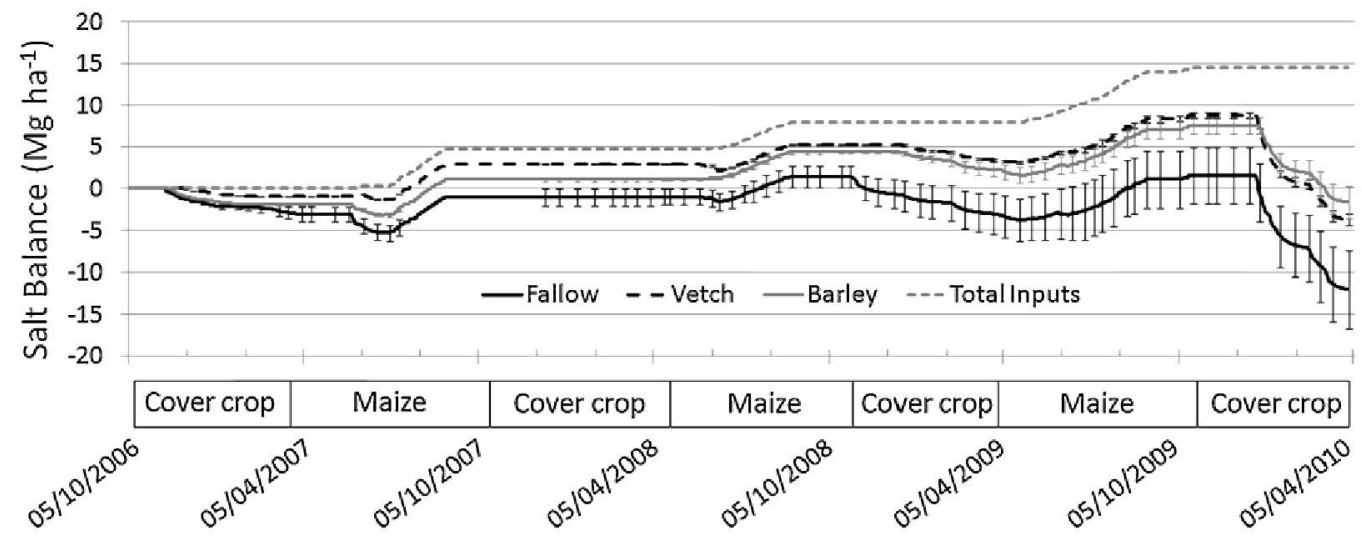

Fig. 3. Cumulative salt intake and salt balance for the fallow, vetch and barley treatments during the experimental period. Error bars represent the standard error.

observed in the upper soil layers of the cover crop treatments but not the fallow, probably owing to abundant rainfall. After harvesting maize in 2008, TDS in the vetch was higher than in the other treatments, but the differences were homogeneously distributed along the profile.

\section{Discussion}

The salt concentration of the soil solution collected at $1.2 \mathrm{~m}$ was threefold higher than that of the irrigation water. Examination of the ion concentrations in the soil solution and a linear correlation among them indicated that gypsum solubility reactions $\left(\mathrm{CaSO}_{4} \cdot 2 \mathrm{H}_{2} \mathrm{O}\right)$ may govern the soil-solution concentrations in this soil (Tables 4 and 5$)$. The dissolution of sodium chloride $(\mathrm{NaCl})$ and that of other chloride salts and carbonates may also be an important source of salinity. These results are in keeping with regional studies on soil from the terraces of the Taxus river, where the origin of the salinity was mainly attributed to gypsum with sodium chloride and carbonates also present (Roquero et al., 2001). Under these conditions, during periods of low soil water content, salt precipitates and salt loads are expected to diminish in soil layers, whereas, during wet periods, rainwater enhances salt dissolution, thereby increasing salinity and salt leaching risk.

The CC treatments reduced salt leaching with respect to the fallow treatment. As the seasonal trend of the salt concentration in the soil solution did not differ between treatments, salt leaching was related to the length of the drainage period and to the amount of water percolating below $1.2 \mathrm{~m}$. Most drainage and salt leaching occurred during the intercrop period. On average, salt leaching during the intercrop was about $80 \%$ of the total salt leaching in the maize/intercrop cycle. These results agree with those of Caballero et al. (2001) and Gabriel et al. (2012), who emphasised that, in irrigated systems in which water is adjusted to crop requirements, most leaching takes place during the non-growing season. During the irrigation period, salts tend to accumulate in the soil profile because they are not washed out, and they are leached with autumn and winter rainfall. In our experiment, water application was adjusted to the crop requirements, and salt accumulation during the irrigation period was observed every year with TDS always being lower before maize planting than after the harvest.

The CC significantly controlled salt leaching during the irrigation periods of spring 2007 and 2008. Application of excess water during the initial growth stages to ensure crop establishment is a common practice, and it is a cause of water percolation below the root zone (Vázquez et al., 2005). Water depletion due to the $\mathrm{CC}$ reduced the water content of the soil profile relative to the fallow treatment just before maize planting, and so the amounts of drainage and salt leaching were also reduced. This effect was less relevant than during the intercrop period, mainly because salt leaching during the maize crop was less than $20 \%$ of the total salt leaching. The salt leaching and net salt losses observed were in the range reported in the literature; Caballero et al. (2001) reported salt leaching of $20 \mathrm{Mg} \mathrm{ha}^{-1}$ and net salt losses of $6.4 \mathrm{Mg} \mathrm{ha}^{-1}$ over four years in a field experiment in which water irrigation was adapted to crop needs. Bustos et al. (1996) reported that salt leaching was 3.4 or $3.8 \mathrm{Mg} \mathrm{ha}^{-1}$ in a maize crop cycle, depending on the source and salinity of the irrigation water.

Table 6

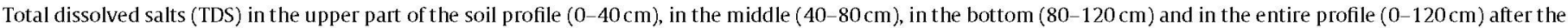
cover crops and maize harvest.

\begin{tabular}{|c|c|c|c|c|c|c|c|c|c|}
\hline \multirow[t]{2}{*}{ Depth $(\mathrm{cm})$} & \multirow[t]{2}{*}{ Treatment } & \multicolumn{8}{|c|}{ Total dissolved salts ( $\left.\mathrm{Mg} \mathrm{ha}^{-1}\right)$} \\
\hline & & October-06 & April-07 & October-07 & April-08 & October-08 & April-09 & October-09 & April-10 \\
\hline \multirow[t]{3}{*}{$0-40$} & Barley & $4.75 \mathrm{a}$ & $2.24 \mathrm{a}$ & $3.27 \mathrm{a}$ & $3.56 \mathrm{a}$ & $5.31 \mathrm{a}$ & $3.68 \mathrm{a}$ & $0.87 \mathrm{a}$ & $1.67 \mathrm{a}$ \\
\hline & Fallow & $4.75 \mathrm{a}$ & $2.02 \mathrm{a}$ & $3.40 \mathrm{a}$ & $4.22 \mathrm{~b}$ & $5.40 \mathrm{a}$ & $3.60 \mathrm{a}$ & $0.79 \mathrm{a}$ & $3.49 \mathrm{~b}$ \\
\hline & Vetch & $4.75 \mathrm{a}$ & $2.06 \mathrm{a}$ & $4.57 \mathrm{~b}$ & $3.31 \mathrm{a}$ & $4.91 \mathrm{a}$ & $3.48 \mathrm{a}$ & $0.86 \mathrm{a}$ & $1.84 \mathrm{a}$ \\
\hline \multirow[t]{3}{*}{$40-80$} & Barley & $5.05 \mathrm{a}$ & $5.28 \mathrm{a}$ & $4.83 \mathrm{a}$ & $3.81 \mathrm{a}$ & $5.92 \mathrm{a}$ & $5.59 \mathrm{a}$ & $1.41 \mathrm{a}$ & $4.36 \mathrm{a}$ \\
\hline & Fallow & $5.05 \mathrm{a}$ & $5.89 \mathrm{a}$ & $5.31 \mathrm{ab}$ & $4.98 \mathrm{~b}$ & $4.69 \mathrm{a}$ & $5.24 \mathrm{a}$ & $0.94 \mathrm{a}$ & 4.79 a \\
\hline & Vetch & $5.05 \mathrm{a}$ & $5.45 \mathrm{a}$ & $5.85 \mathrm{~b}$ & $4.06 \mathrm{a}$ & $5.12 \mathrm{a}$ & $5.22 \mathrm{a}$ & $1.39 \mathrm{a}$ & $4.09 \mathrm{a}$ \\
\hline \multirow[t]{3}{*}{$80-120$} & Barley & $5.65 \mathrm{a}$ & $6.52 \mathrm{a}$ & $6.33 \mathrm{a}$ & $5.13 \mathrm{a}$ & $6.65 \mathrm{a}$ & $6.59 \mathrm{a}$ & $1.71 \mathrm{a}$ & $6.03 \mathrm{a}$ \\
\hline & Fallow & $5.65 \mathrm{a}$ & $7.12 \mathrm{a}$ & $6.29 \mathrm{a}$ & $5.32 \mathrm{a}$ & $5.37 \mathrm{a}$ & $6.74 \mathrm{a}$ & $1.28 \mathrm{a}$ & $6.58 \mathrm{a}$ \\
\hline & Vetch & $5.65 \mathrm{a}$ & $6.50 \mathrm{a}$ & $6.38 \mathrm{a}$ & $5.65 \mathrm{a}$ & $5.76 \mathrm{a}$ & $6.81 \mathrm{a}$ & $1.45 \mathrm{a}$ & $5.58 \mathrm{a}$ \\
\hline \multirow[t]{3}{*}{$0-120$} & Barley & $15.44 \mathrm{a}$ & $14.04 \mathrm{a}$ & $14.44 \mathrm{a}$ & $12.50 \mathrm{a}$ & $17.88 \mathrm{a}$ & $15.85 \mathrm{a}$ & $3.99 \mathrm{a}$ & $12.06 \mathrm{a}$ \\
\hline & Fallow & $15.44 \mathrm{a}$ & $15.04 \mathrm{a}$ & $15.00 \mathrm{a}$ & $14.52 \mathrm{~b}$ & $15.46 \mathrm{a}$ & $15.58 \mathrm{a}$ & $3.01 \mathrm{a}$ & $14.86 \mathrm{~b}$ \\
\hline & Vetch & $15.44 \mathrm{a}$ & $14.01 \mathrm{a}$ & $16.80 \mathrm{~b}$ & $13.02 \mathrm{a}$ & $15.78 \mathrm{a}$ & $15.50 \mathrm{a}$ & $3.70 \mathrm{a}$ & $11.52 \mathrm{a}$ \\
\hline
\end{tabular}

Within measuring date and depth, treatments followed by different letter are significantly different at $P<0.05$ by Duncan. 


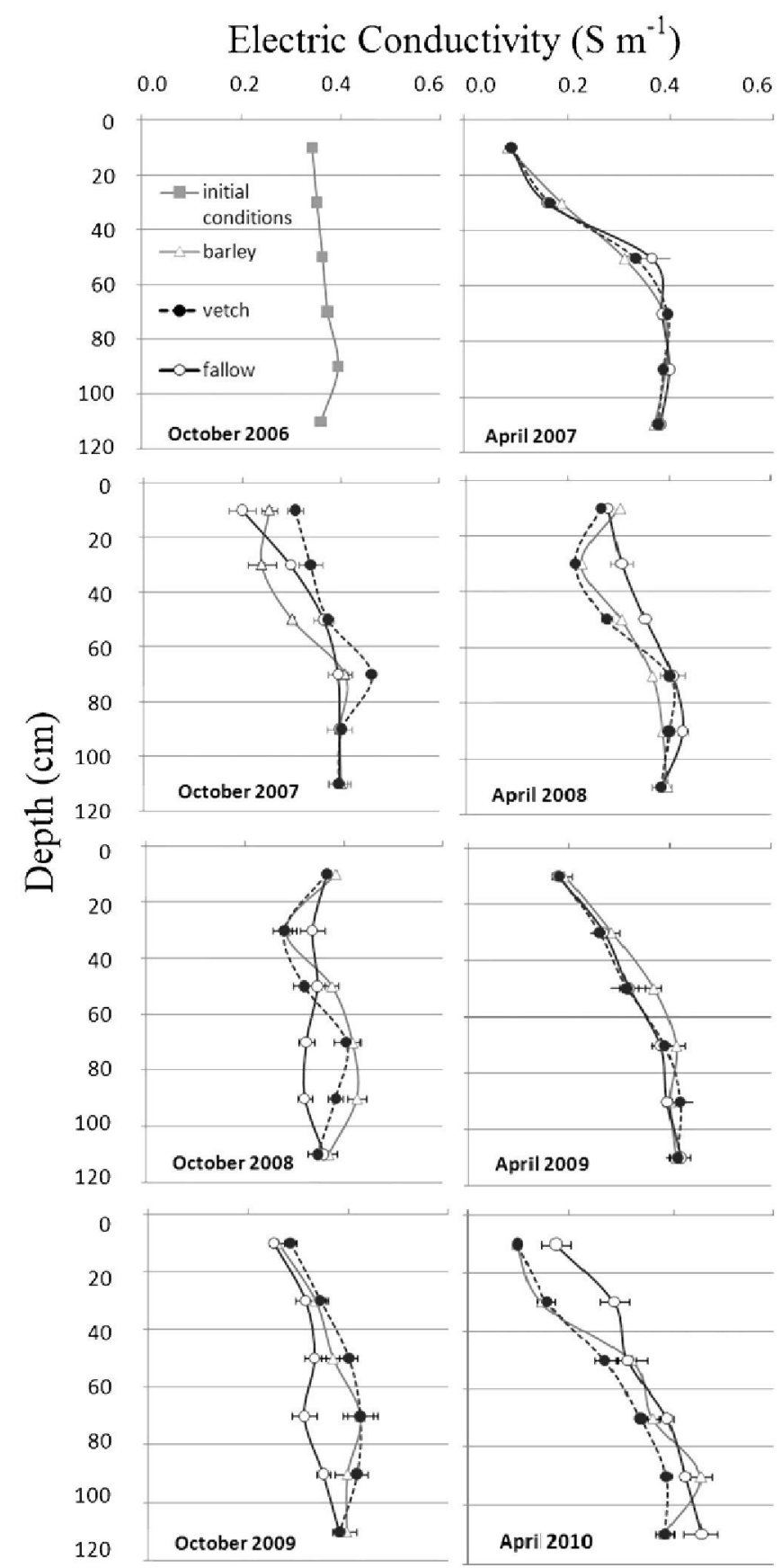

Fig.4. Distribution of the saturated paste extract soil electrical conductivity $\left(\mathrm{S} \mathrm{m}^{-1}\right)$ by depth at the maize harvest and at the end of the cover crop growing season, as influenced by cover crop treatment. Error bars represent the standard error.

Net salt losses were reduced with the $\mathrm{CC}$, as the salt inputs were the same in all of the treatments, but salt leaching was lower in the vetch and barley treatments. In the fallow treatment, net salt gain periods rarely occurred, whereas with the CC they were more prolonged. The wet autumn of 2009/2010 precluded any net salt gains in the vetch and barley treatments by the end of the experiment. Therefore, when water is adjusted to crop needs, rainfall during the non-growing season has an important role in the long-term sustainability of the cropping system. Under semiarid conditions, the amount and distribution of rainfall shows high annual variability (from $72 \mathrm{~mm}$ to $350 \mathrm{~mm}$ during the non-growing season in our study). In dry years, leaching during the intercrop season is low, and salt accumulation may be observed before planting the cash crop in the spring (i.e., April in our field trial). In wet years, occasional periods of heavy rainfall induce drainage and salt leaching. In our experiment, the $\mathrm{CC}$ did not increase salt accumulation in the soil profile when compared to the fallow treatment. Moreover, in two years, the salt accumulation in the CC treatments was lower than in the fallow. The difference was clear in the upper layers, where the subsequent cash crop is established. This effect of $\mathrm{CC}$ could be explained by the reduction of water content in the soil profile during the non-growing season, particularly in the top soil, where more roots are present. In the dryer upper horizons, the dissolution of soil salts declined, and precipitation was enhanced. Water content is known to control the solubility equilibrium of salts and irrigation schedules that maintain low water content are known to prevent soil salt dissolution (Caballero et al., 2001). Another possible explanation is that cover crop biomass, either above or below ground, could prevent from increasing soil salt accumulation. The average aboveground biomass for the $\mathrm{CC}$ was $2883 \mathrm{~kg} \mathrm{dm} \mathrm{ha}^{-1}$, and the average root biomass measured in the upper $0.40 \mathrm{~m}$ was $2580 \mathrm{~kg} \mathrm{dm} \mathrm{ha}^{-1}$ (Gabriel and Quemada, 2011). Considering an average plant nutrient concentration of $3.6 \%$ (Ayers and Wescott, 1985) the nutrients retained in the CC biomass would be approximately $191 \mathrm{~kg} \mathrm{ha}^{-1}$. This value is far from the difference in TDS between the fallow and CC treatments $\left(0.75 \mathrm{Mg} \mathrm{ha}^{-1}\right.$ in April 2008 and 1.7 in April 2010), so a direct effect of plant uptake on salt accumulation does not seem feasible. Nevertheless, some authors report that root biomass is much greater than what we actually observed, and its role in nutrient retention might be underestimated (Thorup-Kristensen, 2001). Research is needed to understand this beneficial effect of CC on soil salinity, which may suggest a new role for cover cropping in agricultural systems in which salt accumulation is a major problem.

In this experiment, the salinity of the irrigation water was low, and there were no restrictions on its crop application. Therefore, soil salinity was more closely related to the dissolution of soil salts and to changes in soil water content than to salt addition from external sources. These results show that $\mathrm{CC}$ can be introduced during the intercrop period without elevating soil salinity in the midterm, provided that occasional periods of abundant rainfall induced salt leaching. Wet intercrop seasons able to induce drainage (rainfall $>250 \mathrm{~mm}$ from November to February of the following year) occurred in the area at least once every 7 year, and with a mean of once every 4 year for the past 90 -year period (Almarza et al., 1996). Care should be taken when applying our results to agricultural systems irrigated with low-quality water. In these cases, the rate of salinisation depends on the amount of saline water applied, and hazardous levels can be attained if water application does not exceed the amount of water used by the crop (Oster, 1994). Introducing CC might have beneficial effects, as observed in our experiment, but specific studies should be conducted to evaluate their potential.

\section{Conclusions}

Replacing fallow with a cover crop reduced salt leaching below $1.2 \mathrm{~m}$ deep in an irrigated maize cropping system. The total salt leached in the fallow treatment over 3.5 years was $26 \mathrm{Mg} \mathrm{ha}^{-1}$, whereas less than $18 \mathrm{Mg} \mathrm{ha}^{-1}$ leached when using either vetch or barley as a cover crop. Irrigation water application was adjusted to the requirements of the maize, and most of the drainage and salt leaching occurred during the intercrop period. The reduced salt discharge in the cover crop treatments was not related to a lower salt concentration in the soil solution, but rather to reduced water percolation below the root zone. As a consequence, net salt losses were reduced in the cover crop treatments, and periods of salt gain occurred more often than in the fallow treatment. Nevertheless, 
by the end of the experimental period, net salt losses occurred in all treatments, owing to occasional periods of heavy rainfall that induced drainage and salt leaching. Therefore, the introduction of CC into irrigated systems should include cautionary measures for farmers to control excessive soil salinity after several years with a dry intercrop period.

During the maize cropping period, salinity increased in the soil profile for all treatments, but the fallow treatment was more prone than the $\mathrm{CC}$ to accumulate salt in the soil profile during the intercrop period. After two years, salinity in the upper soil layers was higher in the fallow than in the cover crop treatments. This effect could be attributable to the enhanced salt dissolution in the fallow treatment (owing to its higher water content) increasing the potential for salt accumulation. This beneficial effect of CC on soil salinity may be relevant in cropping systems in which soil accumulation is a problem, particularly because subsequent cash crops are more sensitive to soil salinity in their early growth stages.

\section{Acknowledgments}

This work was funded by the Comision Interministerial de Ciencia y Tecnología of Sapin and by the Comunidad de Madrid (project AGRISOST, S2009/AGR-1630). We would like to thank the staff from La Chimnea field station (Instituto Madrileño de Investigación y Desarrollo Agrario) for their helpful assistance.

\section{References}

Allen, R.G., Pereira, L.S., Raes, D., Smith, M., 1998. FAO 56 Irrigation and Drainage Paper: Crop Evapotranspiration. Food and Agriculture Organization, Rome.

Almarza, C.M., López, J.A., Flores, C., 1996. Homogeneidad y variabilidad de los registros históricos de precipitaciones en España. Ministerio de Medio Ambiente, Madrid, Spain.

American Public Health Association, 1995. Standard Methods for the Examination of Water and Wastewater, 19th ed. Am. Publ. Health Assoc. Am. Water Works Assoc., and Water Environ. Fed., Washington, DC, US.

Aragüés, R., Tanji, K.K., 2003. Water quality of irrigation return flows. In: Encyclopedia of Water Science. Marcel Dekker, New York, pp. 502-506.

Artieda, O., Herrero, J., Drohan, P.J., 2006. Refinement of the differential water loss method for gypsum determination in soils. Soil Sci. Soc. Am. J. 70, 1932-1935.

Ayers, R.D., Wescott, D.W., 1985. Water quality for agriculture. FAO Irrg. And Dr. Paper 29, Rev 1. Food and Agriculture Organization of the United Nations, Rome.

Bustos, A., Román, R., Caballero, R., Díez, J.A., Cartagena, M.C., Vallejo, A., Caballero, A., 1996. Water and solute movement under conventional corn in central Spain. II. Salt leaching. Soil Sci. Soc. Am. J. 60, 1536-1540.

Caballero, R., Bustos, A., Román, R, 2001. Soil salinity under traditional and improved irrigation schedules in central Spain. Soil Sci. Soc. Am. J. 65, 1210-1218.

Causapé, J., Quilez, D., Aragues, R., 2004. Assessment of irrigation and environmental quality at the hydrological basin level - II. Salt and nitrate loads in irrigation return flows. Agric. Water Manage. 70, 211-228.

Díez, J.A., Caballero, R., Román, R., Tarquis, A., Cartagena, M.C., Vallejo, A., 2000. Integrated fertilizer and irrigation management to reduce nitrate leaching in central Spain. J. Environ. Qual. 29, 1539-1547.

FAOSTAT. Aquastat, http://www.fao.org/nr/water/aquastat/main/index.stm (verified on 1.6.12)

Feng, Z.Z., Wang, X.K., Feng, Z.W., 2005. Soil n and salinity leaching after the autumn irrigation and its impact on groundwater in Hetao irrigation district. China Agric. Water Manage. 71, 131-143.

Gabriel, J.L., Lizaso, J.I., Quemada, M., 2010. Laboratory versus field calibration of Capacitance Probes. Soil Sci. Soc. Am. J. 74, 593-601.
Gabriel, J.L., Quemada, M., 2011. Replacing bare fallow with CC in a maize cropping system: yield, N uptake and fertiliser fate. Eur. J. Agron. 34, 133-143.

Gabriel, J.L., Muñoz-Carpena, R., Quemada, M., 2012. The role of cover crops in irrigated systems: water balance, nitrate leaching and soil mineral nitrogen accumulation. Agric. Ecosyst. Environ. 155, 50-61.

Hontoria, C., Saa, A., Almorox, J., Cuadra, L., Sánchez, A., Gascô, J.M., 2003. The chemical composition of precipitation in Madrid. Water Air Soil Pollut. 146, 35-54.

Keeney, D.R., Nelson, D.W., 1982. Nitrogen - Inorganic forms. En Page, A L. Methods of Soil Analysis. Part 2: Chemical and Microbiological Properties. American Society of Agronomy, Soil Science Society of America, Madison, WI, USA, pp. 643-698.

Lambers, H., 2003. Dryland salinity: a key environmental issue in southern Australia. Plant Soil 257, 5-7.

Loeppert, R.D.,Suarez, D.L., 1996. Carbonate and Gypsum. In: Sparks, D.L. (Ed.), Methods of Soil Analysis. Part 3. Chemical Methods. SSSA Book Series No. 5. ASA and SSSA, Madison, WI, US, pp. 437-474.

Lord, E.I., Shepherd, M.A., 1993. Developments in the use of ceramic cups for measuring nitrate leaching. Soil Sci. 24, 435-449.

Martínez-Cob, A., 2008. Use of thermal units to estimate corn crop coefficients under semiarid climatic conditions. Irrigation Sci. 26, 335-345.

Nelson, D.W., Sommers, L.E., 1996. Total carbon, organic carbon, and organic matter. In: Sparks, D.L. (Ed.), Methods of Soil Analysis. Part 3. Chemical Methods. SSSA Book Series No. 5. ASA and SSSA, Madison, WI, US, pp. 961-1010.

Oster, J.D., 1994. Irrigation with poor quality water. Agric. Water Manage. 25, $271-297$.

Paltineanu, I.C., Starr, J.L., 1997. Real-time soil water dynamics using multisensor capacitance probes: laboratory calibrations. Soil Sci. Soc. Agron. Soil Sci. Soc. Am. 61, 1576-1585.

Papadakis, J., 1966. Climates of the World and Their Agricultural Potentialities. DAPCO, Rome, Italy.

Paranychianakis, N.V., Chartzoulakis, K.S., 2005. Irrigation of Mediterranean crops with saline water: from physiology to management practices. Agric. Ecosyst. Environ. 106, 171-187.

Quemada, M., Cabrera, M.L, 2002. Characteristic moisture curves and maximum water content of two crop residues. Plant Soil 238, 295-299.

Rhoades, J.D., 1996. Salinity: electrical conductivity and total dissolved solids. In: Sparks, D.L. (Ed.), Methods of Soil Analysis. Part 3. Chemical Methods. SSSA Book Series No. 5. ASA and SSSA, Madison, WI, US, pp. 417-435.

Roberson, E.B., Sarig, S., Firestone, M.K., 1991. Cover crop management of polysaccharide-mediated aggregation in an orchard soil. Soil Sci. Soc. Am. J. 55 $734-739$.

Román, R., Caballero, R., Bustos, A., 1999. Field water drainage under traditional and improved irrigation schedules for corn in central Spain. Soil Sci. Soc. Am. J. 63, 1811-1817.

Roquero, E., Goy, J.L., Zazo, C., Artienda, O., 2001. Control geomorfológico de la salinidad en suelos aluviales. Cuaternario Geomorfol 15, 95-107.

Soil Survey Staff, 2003. Keys to Soil Taxonomy, Ninth ed. USDA, Natural Resources Conservation Service, Madison, WI, US.

Sumner, M.E., Miller, W.P., 1996. Cation exhange capacity and exhange coefficients. In: Sparks, D.L. (Ed.), Methods of Soil Analysis. Part 3. Chemical Methods. SSSA Book Series No. 5. ASA and SSSA, Madison, WI, US, pp. 1201-1229.

Thorup-Kristensen, K., 2001. Are differences in root growth of nitrogen catch crops important for their ability to reduce soil nitrate-N content, and how can this be measured? Plant Soil 230, 185-195.

Unger, P.W., Vigil, M.F., 1998. Cover crops effects on soil water relationships. J. Soil Water Conserv. 53, 200-207.

Vanclooster, M., Viaene, P., Diels, J., Christiaens, K, 1996. WAVE: A Mathematical Model for Simulating Water and Agrochemicals in the Soil and Vadose Environment. En: Reference and User's Manual (Release 2.0). Institute for Land and Water Management, Katholieke Universiteit Leuven, Belgium.

Vázquez, N., Pardo, A., Suso, M.L., Quemada, M., 2005. A methodology for measuring drainage and nitrate leaching in unevenly irrigated vegetable crops. Plant Soil 269, 297-308.

Vázquez, N., Pardo, A., Suso, M.L., Quemada, M., 2006. Drainage and nitrate leaching under processing tomatogrowth with drip irrigation and plastic mulching. Agric. Ecosyst. Environ. 112, 313-323.

Wichelns, D., Oster, J.D., 2006. Sustainable irrigat ion is necessary and achievable, but direct costs and environmental impacts can be substantial. Agric. Water Manage. $86,114-127$. 